\title{
Dermatology
}

Dermatology 2010;220:44-45

DOI: $10.1159 / 000264668$

\section{Intralesional Photodynamic Therapy: A Comment on 'Pretreatment to Enhance Protoporphyrin IX Accumulation in Photodynamic Therapy' by Gerritsen et al.}

\author{
Daniele Torchia ${ }^{\mathrm{a}-\mathrm{c}}$, Pietro Cappugi ${ }^{\mathrm{a}}$ \\ ${ }^{a}$ Italian Group of Radiofrequencies and Photodynamic Therapy \\ (GIRTeF) and b ${ }^{b}$ Department of Experimental Pathology and \\ Oncology, University of Florence, Florence, Italy; ${ }^{\mathrm{C}}$ Department \\ of Dermatology and Cutaneous Surgery, University of Miami \\ Miller School of Medicine, Miami, Fla., USA
}

\section{Key Words}

Photodynamic therapy, intralesional $\cdot 5$-Aminolevulinic acid

We read with interest a paper published in a recent issue of Dermatology [1], in which Gerritsen et al. review the procedures aimed at enhancing protoporphyrin IX accumulation before light application in photodynamic therapy (PDT). The authors did not mention intralesional PDT, a seldom used technique which potential, though, is in our opinion underrecognized and underestimated.

As shown in table 1, intralesional PDT has been reported to be an effective and safe treatment for skin metastases of breast cancer [2], superficial and nodular basal-cell carcinoma $[3,4,6,7]$, squamous-cell carcinoma [4-7], Paget's disease [5] and acne vulgaris [8]. We have also successfully treated anogenital condylomata [unpubl. data].

Performing intralesional PDT is less time-consuming than several other pretreatment procedures [1]. Moreover, a study showed that the fluorescence induced by the intralesional injection of the prodrug was present as early as $4 \mathrm{~h}$ [9]; nonetheless, the time necessary to allow the conversion of the prodrug into the final photosensitizer is likely to be much shorter, as incubations $<1 \mathrm{~h}$ were shown to be effective as well $[2,8]$. It has also been proposed that intralesional PDT may be particularly effective in inflammatory disorders in which the epidermal surface is intact or nearly intact and the dermis thickened for physiological (scalp) or pathological reasons (morphea) [10]. In black patients, intralesional PDT may overcome, if not the diminished penetration of

Table 1. Reported studies on the use of intralesional PDT for skin diseases

\begin{tabular}{|c|c|c|c|c|c|c|c|}
\hline $\begin{array}{l}\text { Ref. } \\
\text { No. }\end{array}$ & Condition & $\begin{array}{l}\text { Number of } \\
\text { patients }\end{array}$ & Formulation & $\begin{array}{l}\text { Incubation } \\
\mathrm{h}\end{array}$ & $\begin{array}{l}\text { Light source } \\
\text { (fluence) }\end{array}$ & $\begin{array}{l}\text { Number of } \\
\text { sessions }\end{array}$ & Results \\
\hline 2 & $\begin{array}{l}\text { Skin metastases } \\
\text { of breast cancer }\end{array}$ & 9 & $1.5 \% \mathrm{TPPS}_{4}$ in saline & 0.75 & $\begin{array}{l}\text { Argon dye laser } \\
630 \mathrm{~nm}\left(150 \mathrm{~cm}^{-2}\right)\end{array}$ & $5-31$ & $\begin{array}{l}\text { Complete clearance } \\
\text { in } 3 \text { patients, good } \\
\text { results in } 2\end{array}$ \\
\hline 3 & sBCC & 1 & $10 \%$ ALA in saline & 4 & $\begin{array}{l}\text { Visible light } \\
\left(500 \mathrm{~J} \mathrm{~cm}^{-2}\right)\end{array}$ & 1 & Complete clearance \\
\hline 4 & $\begin{array}{l}\text { SCC } \\
\text { BCC }\end{array}$ & $\begin{array}{r}8 \\
11\end{array}$ & $\begin{array}{l}0.02 \% \text { hypericin in } \\
\text { ethanol, glycerol } \\
\text { and PEG } 400\end{array}$ & NR & $\begin{array}{l}\text { Visible light } \\
\left(86 \mathrm{~J} \mathrm{~cm}^{-2}\right)\end{array}$ & $\begin{array}{r}10-25 \\
9-18\end{array}$ & $\begin{array}{l}\text { Complete clearance } \\
\text { in } 3 \text { patients, good } \\
\text { results in } 7\end{array}$ \\
\hline 5 & Paget's disease & 1 & $10 \%$ ALA in saline & 4 & $\begin{array}{l}\text { Visible light } \\
\left(500 \mathrm{~J} \mathrm{~cm}^{-2}\right)\end{array}$ & 10 & Complete clearance \\
\hline 8 & Acne vulgaris & 10 & $11.8 \%$ ALA in saline & 0.5 & $\begin{array}{l}\text { Pulsed dye laser } \\
\left(7.5 \mathrm{~J} \mathrm{~cm}^{-2}\right)\end{array}$ & $2-3$ & $\begin{array}{l}\text { Better results than } \\
\text { conventional PDT }\end{array}$ \\
\hline
\end{tabular}

Ref. = Reference; $\mathrm{sBCC}=$ superficial basal-cell carcinoma; $\mathrm{SCC}=$ squamous-cell carcinoma; $\mathrm{nBCC}=$ nodular basal-cell carcinoma; $\mathrm{TPPS}_{4}=$ meso-tetra-( $p$-sulphophenyl)porphin; ALA = 5-aminolevulinic acid; PEG = polyethylene glycol; NR = not reported .

\section{KARGER}

Fax +4161306 1234

E-Mail karger@karger.ch

www.karger.com
(C) 2009 S. Karger AG, Basel 
light due to the increased melanin filter, at least the increased thickness of the stratum corneum [11]. Also according to our experience, this technique does not affect the compliance of patients [6] and causes fewer side effects (erythema, crusting) in the postirradiation period than conventional topical PDT [8].

The only disadvantage of intralesional PDT may be the difficulty to treat simultaneously relatively large areas of field cancerization.

Evidence-based studies addressing the effectiveness, safety profile and effectiveness/cost ratio of intralesional PDT versus conventional topical PDT are therefore warranted.

\section{References}

1 Gerritsen MJP, Smits T, Kleinpenning MM, van de Kerkhof PCM, van Erp PEJ: Pretreatment to enhance protoporphyrin IX accumulation in photodynamic therapy. Dermatology 2009;218:193-202.

2 Lapes M, Petera J, Jirsa M: Photodynamic therapy of cutaneous metastases of breast cancer after local application of meso-tetra-(para-sulphophenyl)-porphin (TPPS4). J Photochem Photobiol B 1996;36:205207.

3 Fink-Puches R, Wolf P, Kerl H: Photodynamic therapy of superficial basal cell carcinoma by instillation of aminolevulinic acid and irradiation with visible light. Arch Dermatol 1997;133:1494-1495.

4 Alecu M, Ursaciuc C, Hãlãlãu F, Coman G, Merlevede W, Waelkens E, de Witte P: Photodynamic treatment of basal cell carcinoma and squamous cell carcinoma with hypericin. Anticancer Res 1998;18:46514654 .
5 Henta T, Itoh Y, Kobayashi M, Ninomiya Y, Ishibashi A: Photodynamic therapy for inoperable vulval Paget's disease using delta-aminolaevulinic acid: successful management of a large skin lesion. Br J Dermatol 1999;141:347-349.

-6 Cappugi P, Mavilia L, Campolmi P, Reali EF, Mori M, Rossi R: New proposal for the treatment of nodular basal cell carcinoma with intralesional 5-aminolevulinic acid. J Chemother 2004;16:491-493.

7 Chapas A, Zeltser R, Geronemus R, Gilchrest B: Intralesional photodynamic therapy of nonmelanoma skin cancer. Lasers Surg Med 2006; 38(suppl 18):27.

8 Ryou JH, Lee SJ, Park YM, Kim HO, Kim HS: Acne-photodynamic therapy with intra-lesional injection of 5-aminolevulinic acid. Photodermatol Photoimmunol Photomed 2009;25:57-58.

-9 Peng Q, Warloe T, Moan J, Heyerdahl H, Steen HB, Nesland JM, Giercksky KE: Distribution of 5-aminolevulinic acid-induced porphyrins in noduloulcerative basal cell carcinoma. Photochem Photobiol 1995;62: 906-913.

10 Torchia D: Photodynamic therapy on intact and/or thick skin. Clin Exp Dermatol 2009;34:e327.

11 Ross EV, Romero R, Kollias N, Crum C, Anderson RR: Selectivity of protoporphyrin IX fluorescence for condylomata after topical application of 5-aminolaevulinic acid: implications for photodynamic treatment. Br J Dermatol 1997;137:736-742.

Daniele Torchia

1390 Ocean Drive, Suite 401

Miami Beach, FL 33139 (USA)

Tel. +1 786329 0414, Fax +1 3052439153

E-Mail daniele.torchia@unifi.it 